\title{
Peranan Teknologi Nuklir Di Bidang Arkeologi Indonesia Dan Pengembangannya
}

Faisal Wisjachudin; F. Lahagu; Djoko Widodo; Kris Tri Basuki; A. Taftazani; Suci Widayati

Keywords: absolute, dating, method, theory, practices, analysis

\section{How to Cite:}

Wisjachudin, F., Lahagu, F., Widodo, D., Basuki, K. T., Taftazani, A., \& Widayati, S. (2000). Peranan Teknologi Nuklir Di Bidang Arkeologi Indonesia Dan Pengembangannya. Berkala Arkeologi, 20(1), 140-150. https://doi.org/10.30883/jba.v20i1.813

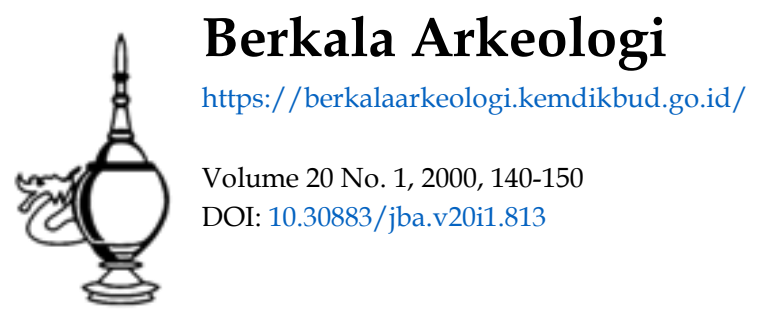

\section{(c) (†) (2)}

This work is licensed under a Creative Commons Attribution-NonCommercial-ShareAlike 4.0 International License. 


\title{
PERANAN TEKNOLOGI NUKLIR DI BIDANG ARKEOLOGI INDONESIA DAN PENGEMBANGANNYA*
}

\author{
Wisjachudin Faisal, F.Lahagu, Djoko Widodo, Kris Tri Basuki, \\ A.Taftazani, Suci Widayati \\ (Pusat Penelitian Nuklir Yogyakarta)
}

\section{Pendahuluan}

Untuk mendukung studi arkeologi seutuhnya sudah barang tentu diperlukan berbagai disiplin ilmu. Teknik nuklir merupakan salah satu bidang ilmu yang dapat berperan pada ilmu tersebut. Seringkali para arkeolog perlu data unsur pendukung dari tinggalan arkeologi tertentu tetapi terbentur pada analisisnya mengingat ada beberapa kendala yang sering dijumpai. misalnya kandungan unsur tersebut relatif sangat kecil sedemikian sehingga bila dianalisis dengan metode konvensional tidak bisa terdeteksi. Sehingga diperlukan metode lain yang dapat mengetahui kandungan unsur kelumit tersebut dengan kesalahan yang relatif kecil. Salah satu diantaranya adalah analisis pengaktifan neutron. Dalam analisis pengaktifan neutron ini, cuplikan diiradiasi dengan neutron (misalnya dalam reaktor atom). Sebagian dari inti atom penyusun cuplikan akan menangkap neutron dan berubah menjadi inti radioaktif (radionuklida). Radionuklida yang terbentuk ini memancarkan zarah beta dan sinar gamma yang berbeda-beda tenaganya tergantung dari jenis inti atomnya. Dengan mengukur besarnya tenaga yang dipancarkan oleh radionuklida dalam cuplikan dapat dilakukan analisis kualitatif unsur-unsur yang terdapat dalam cuplikan. Selanjutnya analisis kuantitatif dapat dilakukan secara komparatif dengan membandingkan intensitas sinar gamma radionuklida dalam cuplikan dengan standar yang diperlakukan sama.

Salah satu dari atribut pokok arkeologi adalah studi kebudayaan pada ruang dan waktu tertentu. Timbulnya spekulasi pada interpretasi beberapa kasus tentang proses sejarah kebudayaan Indonesia dapat mengakibatkan adanya bingkai kosong dalam gambaran tentang rentang kebudayaan, hal ini adalah salah satu akibat masih terbatasnya pemanfaatan analisis pertanggalan mutlak bagi studi arkeologi di Indonesia. Sesuai dengan perkembangan ilmu dan teknologi maka metoda pertanggalan mutlak yang dinilai cukup efektif oleh disiplin arkeologi adalah analisis pertanggalan radiokarbon (radiocarbon dating). Metoda ini dinilai lebih akurat dan hasilnya dapat mentransformasikan pengertian kita pada masa lampau, membantu arkeolog dalam penyusunan kronologi budaya (Renfrew \& Bahn Paul, 1991). Diharapkan hasil pertanggalan absolut dapat memberikan data dukung bagi perkembangan budaya pada

\footnotetext{
- Pernah disampaikan pada Seminar internasional. Seminar Arkeologi Indonesia Perancis di Hotel Sahid Garden Yogyakarta pada tanggal 25-27 September 1995.
} 
masa lampau dengan lebih akurat. Studi pertanggalan absolut khususnya pertanggalan radiokarbon (C-14) pada berbagai situs di Indonesia belum pernah dilakukan sebelumnya. PPNY-BATAN bekerjasama dengan Pusat Penelitian Arkelogi Nasional, Balai Arkeologi Yogyakarta, dan Pusat Studi yang lain telah melakukan berbagai studi pertanggalan khususnya pertanggalan radiokarbon serta analisis unsur pada berbagai tinggalan arkeologi, baik dengan analisis pendar sinar- $\mathrm{x}$ maupun analisis pengaktifan neutron (menggunakan reaktor Kartini).

Pertanggalan tinggalan arkeologi tertentu dapat dilakukan dengan dua cara yaitu pertanggalan mutlak (absolut) dan pertanggalan nisbi (relatif). Pertanggalan mutlak sering disebut juga sebagai pertanggalan kronometris karena penentuan masa (umur) yang dilakukan masih dalam batas-batas tahun kalender, sedangkan pertanggalan nisbi adalah menentukan masa dengan memperbandingan masa sesuatu dengan yang lain misalnya membandingkan masa (umur) fauna yang terdapat pada tempat itu dengan kompleks fauna yang sudah diketahui umurnya di tempat lain. Pertanggalan radiokarbon dapat dipergunakan untuk menentukan umur atau urutan kronologis sampai dengan \pm 45.000 tahun sebelum sekarang (BP), walaupun demikian masa 45.000 tahun tersebut telah meliputi bagian penting dalam perkembangan budaya di Asia Tenggara sejak zaman Paleolithik akhir hingga sekarang (Jacob, 1971).

PPNY BATAN Yogyakarta disamping telah melakukan penelitian pertanggalan radiokarbon juga telah melakukan penelitian dan pengembangan analisis pengaktifan neutron menggunakan fasilitas reaktor Kartini. Analisis ini untuk mendetcksi unsur-unsur kelumit (trace element) secara serentak dalam orde seper sejuta (ppm). Alat yang digunakan disamping Reaktor juga perangkat spektrometri gamma. Analisis lain yang mirip tetapi tanpa bantuan Reaktor adalah analisis pendar sinar-x.

Dalam perkembangan penelitian tentang sejarah kebudayaan di Indoncsia masih banyak celah-celah yang lemah, salah satu diantaranya adalah sangat terbatasnya bahkan minus informasi kronologi yaitu pertanggalan obyek amatan. Dengan diketahui harga pertanggalan tersebut maka alur jenjang kehidupan prasejarah dapat dilakukan rekontruksi. Hal tersebut di atas termasuk studi yang menyangkut proses atau tempo evolusi dalam kerangka waktu. Sedangkan yang menyangkut kerangka ruang dalam hal ini lingkungan salah satunya adalah menentukan kadar unsur yang ada dalam cuplikan arkeologi. Sehingga disamping upaya merekonstruksi budaya masa lalu dapat juga diupayakan rencana tata ruang masa datang. Misalnya lokasi transmigrasi, lokasi industri, lokasi energi, dan sebagainya. 


\section{Metode}

\section{A. Pertanggalan Radiokarbon}

Pelaksanaan diawali dengan observasi lingkungan sekitar situs guna pertimbangan dalam penentuan kotak gali (lubang uji) ekskavasi. Berdasarkan hasil observasi di lapangan tersebut dapat menentukan gambaran umum letak lubang uji (selanjutnya disingkat LU) yaitu di bagian belakang, depan, sebelah kiri dan kanan suatu situs di luar maupun di dalam pagar dengan jarak tidak terlalu jauh dari situs yang bersangkutan.

Cuplikan untuk metode ini dititik beratkan pada tinggalan/sisa bahan organik : arang, kerang serta bahan lain misalnya tulang dan sebagainya. Pada saat pencuplikan (sampling) ada beberapa hal yang perlu diperhatikan, yang pertama cara pengambilannya harus menggunakan alat yang tidak mengandung karbon, yang kedua setelah diambil perlu di angin-anginkan dahulu sampai kering (untuk menghindari terjadinya jamur), yang ketiga wadah cuplikan sebaiknya dari bahan logam misalnya alumunium foil. Sedangkan sebagai data pembanding berupa tinggalan artefaktual benupa : keramik, mata uang, batu prasasti dan sebagainya.

Perlakuan awal berupa pencucian cuplikan dengan air biasa, dibersihkan dari pengotorpengotor terutama tanah, dibilas dengan akuades. Kemudian dilakukan perlakuan pencucian dengan metoda asam-basa-asam (A-B-A), yaitu direndam dengan asam $(\mathrm{HCl}$ $0,2 \mathrm{~N})$, kemudian dicuci dengan akuades, diikuti dengan basa $(\mathrm{NaOH} 0,2 \mathrm{~N})$ dan dicuci dengan akuades, diakhiri dengan pencucuian asam sama dengan yang tersebut di atas. Setelah dikeringkan pada suhu $125^{\circ} \mathrm{C}$, arang tersebut ditimbang \pm 5 gram, dan siap untuk dibakar dengan proses kering dalam alat benzene synthesizer menjadi $\mathrm{CO}_{2}$. Sebagai standar digunakan asam oksalat NBS $4990 \mathrm{C}$ cara pembakarannya menggunakan proses basah. $\mathrm{CO}_{2}$ yang terbentuk dari pembakaran tersebut direaksikan dengan logam litium panas sehingga terbentuk litium karbida, $\mathrm{Li}_{2} \mathrm{C}_{2}$. Setelah itu litium karbida direaksikan dengan air sehingga akan melepaskan asetilen, $\mathrm{C}_{2} \mathrm{H}_{2}$. Gas asetilen ini kemudian dialirkan melalui kolom pemurnian untuk menghilangkan sisa air, oksida-oksida sulfur dan nitrogen serta pengotor lainnya. Gas asetilen tersebut akhirnya dialirkan menuju kolom yang berisi katalisator kromium. Katalisator ini membantu terjadinya proses trimerisasi asetilen menjadi benzen $\left(\mathrm{C}_{6} \mathrm{H}_{6}\right)$. Benzen yang terperangkap pada butir-butir katalisator dalam kolom dilepaskan dengan pemanasan dan ditampung dalam kolom perangkap gelas yang bagian luarnya telah didinginkan dengan campuran dry ice-propanol. Benzen dari cuplikan ini kemudian ditimbang dan ditambah bahan pengelip cair (sintilator cair) dan ditempatkan pada wadah (vial), maka analisis dilanjutkan dengan pencacahan radioaktivitas ${ }^{14} \mathrm{C}$ dengan menggunakan alat pencacah kelip cair latar rendah (low level liquid scintillation counter)(Faisal, et.al., 1991;Faisal et.al., 1993). Konversi dari cuplikan asli menjadi benzen dimaksudkan untuk memperkaya kadar ${ }^{14} \mathrm{C}$ sehingga radioaktivitasnya dapat diukur dengan lebih teliti. Dengan membandingkan aktivitas 
jenis ${ }^{14} \mathrm{C}$ dari cuplikan dengan standar maka akan dapat dihitung pertanggalan (umur) cuplikan. Pada perhitungan umur menggunakan metode pertanggalan radiokarbon ini ada koreksi-koreksi yang perlu diperhatikan yaitu :

1.Koreksi efek fraksinasi isotop karbon

2.Koreksi lingkaran pohon (tree-ring correction)

Koreksi efek fraksinasi isotop memerlukan pengukuran $\mathrm{d}^{13} \mathrm{C}$ menggunakan teknik khusus dalam spektrometer massa. Koreksi lingkaran pohon dapat dilakukan dengan perangkat lunak komputer buatan Groningen.

Adapun rumus umur (harga pertanggalan) dengan koreksi fraksinasi isotop adalah sebagai berikut :

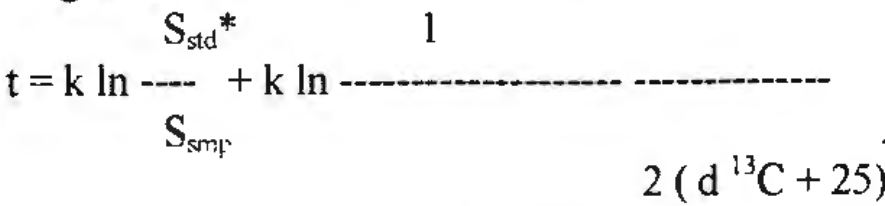

$$
\begin{aligned}
& 1 \text { - }
\end{aligned}
$$

$\mathrm{S}_{\mathrm{sd}}{ }^{*} \quad=$ aktivitas spesifik asam oksalat terkoreksi (sbg.standar)

$\mathrm{S}_{\mathrm{smp}} \quad=$ aktivitas spesifik dari cuplikan

$\mathrm{t}=$ umur dalam BP (before present, sebelum saat ini)

$\mathrm{d}^{13} \mathrm{C}=$ harga delta ${ }^{13} \mathrm{C}$ (koreksi fraksinasi isotop)

$\mathrm{k} \quad=$ konstanta $(8033)$

\section{B. Analisis Pendar Sinar-x dan Analisis Pengaktifan Neutron :}

Sinar $\mathrm{x}$ dapat dimanfaatkan di dalam analisis kimia untuk menentukan berbagai unsur, baik penentuan unsur secara kualitatif (jenis unsur) maupun penentuan unsur secara kuantitatif (kadar atau konsentrasi unsur).

Analisis kuantitatif metode sinar-x memerlukan cuplikan pembanding (standar), dengan demikian metode sinar-x termasuk analisis komparatif. Cuplikan yang dianalisis bisa berbentuk padatan (pejal, serbuk), padatan cair (lumpuran) dan cairan.

Salah satu analisis yang memanfaatkan sinar- $\mathrm{x}$ adalah analisis pendar sinar- $\mathrm{x}$ biasa dikenal sebagai XRFA ( $x$-ray fluorescent analysis). Metode analisis ini berdasarkan pengukuran tenaga atau panjang gelombang sinar- $x$ yang dipancarkan oleh atom dari unsur dalam cuplikan (analisis kualitatif) dan konsentrasi unsur ditentukan berdasarkan banyaknya/cacah sinar-x yang dipancarkan (analisis kuantitatif) (Bertin, 1978). 
Aktivasi Pengaktifan Neutron (APN) merupakan teknik analisis kadar unsur dalam cuplikan yang telah banyak digunakan yang cara kerjanya mirip dengan XRFA. Letak perbedaannya pada cara aktivasinya. APN pengaktifannya dengan ditembaki neutron sedangkan pada XRFA ditembaki dengan sumber zat radioaktif pemancar sinar gamma. Adapaun salah satu ciri dari analisis ini kepekaan (sensitivitas) jika dibandingkan dengan metode lain (gravimetri, kolorimetri, spektrografi dan spektrometri massa ) relatif lebih baik ( lihat Gambar. 1).

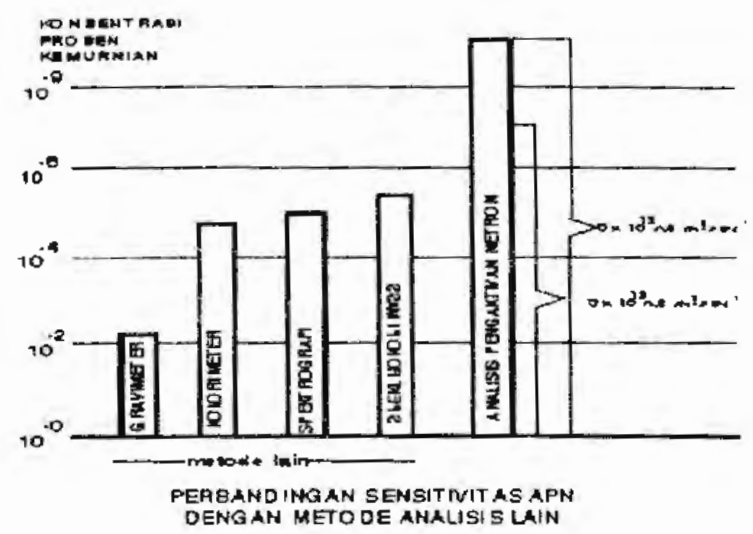

Gambar. 1 Perbandingan sensitivitas/kepekaan metode APN dibandingkan dengan metode analisis (Corliss, 1964).

Analisis kuantitatif pada APN mirip dengan metode sinar-x untuk penentuan unsur-unsur dalam cuplikan, yaitu dengan jalan membandingkan laju cacah cuplikan dengan standar, kadar unsur dalam cuplikan dapat ditentukan dengan rumus dibawah ini (Erdtmann, 1986).

$$
W_{\text {cuplkan }}=\frac{(c p s)_{\text {cuphakan }}}{(c p s)_{\text {standar }}} \times W_{\text {standar }} \ldots \text {... (2) }
$$

$\mathrm{W}=$ kadar yang diperhatikan

cps = laju cacah 
Uji akurasi dilakukan dan dinyatakan dalam persen akurasi :

$$
\text { Akurasi }=\frac{(K u-K s)}{K s} \times 100 \% \ldots .(3)
$$

dengan : $\quad \mathrm{Ku}=$ kadar terukur

$\mathrm{Ks}=$ kadar sertifikat

1. Preparasi cuplikan padat untuk analisis kualitatif

a. Cuplikan padat yang akan dianalisis, terlebih dahulu ditumbuk sampai halus dengan lumpang Agate.

b. Kemudian diayak dengan ukuran minimum 200 mesh, dengan maksud agar butiran-butiran serbuk cuplikan padat mempunyai ukuran yang samadengan ukuran butiran standar.

c. Ditimbang (menurut kebutuhan) serbuk cuplikan padat tersebut diatas, misal 2 gram masukkan dalam plastik klip, siap untuk dicacah dengan waktu tertentu misal 500 detik.

2. Analisis kualitatif dan kuatitatif cuplikan padat dengan alat pendar sinar $x$

a. Cuplikan padat yang telah dipreparasi dan dimasukan ke dalam wadah plastik, letakkan diatas sumber cksitasi dan dicacah selama 500 detik, diulang 3 kali. Tenaga (keV) yang ditampilkan pada layar MCA dapat dicatat (lihat Gambar 2).

b. Unsur-unsur apa saja yang ada pada cuplikan padat tersebut dapat diketahui dengan bantuan tabel tenaga.

c. Untuk analisis kuatitatif perlu dilakukan pembuatan kurva standar konsentrasi vs cacah

d. Cacah dari masing-masing unsur dapat diplotkan pada kurva standar sehingga konsentrasi unsur dapat dihitung.

\section{Analisis kualitatif dan kuatitatif analisis pengaktifan neutron}

1. Kalibrasi tenga vs nomor salur perangkat spektrometri gamma menggunakan standar ${ }^{152} \mathrm{Eu}$.

2. Ditimbang cuplikan dan standar seberat 0.1 gram.

3. Cuplikan dan standar diirradiasi bersama-sama selama 6 jam dalam kelongsong (1 kelongsong berisi 2 cuplikan dan 2 standar).

4. Pendinginan dilakukan selama \pm 15 hari. 
5. Cuplikan dan standar dicacah dengan Spectrometer gamma (lihat Gambar 1)

6. Unsur-unsur apa saja yang ada pada cuplikan padat tersebut dapat diketahui dengan bantuan tabel tenaga.

7. Kadar cuplikan dapat dihitung dengan membandingkan cacah standar (persamaan 2).

\section{Peralatan}

1. Detector $\mathrm{Ge}(\mathrm{Li})$ untuk spek.gamma, $\mathrm{Si}(\mathrm{Li})$ untuk pendar sinar-x

2. Perangkat Spektrometri gamma dan pendar sinar $\mathrm{x}$ dengan pencacah salur ganda

3. Timbangan Sartorius

4. Fasilitas Reaktor Kartini Lazy Susan dengan fluks neutron $1.04 \times 10^{11} \mathrm{~cm}^{-2} \mathrm{~s}^{-1}$

i. Vial Polyethylene

j. Container berlapis timbal

k. Kelongsong

E. Bahan :

1. Cuplikan, Standar SRM-SLl (Standart Reference Material-Sediment Lake 1).

2. Sumber standar Multigamma ${ }^{152} \mathrm{Eu}$

\section{Hasil dan Pembahasan}

Adapun hasil penelitian pada kegiatan yang telah dilakukan meliputi pertanggalan radiokarbon, analisis pengaktifan neutron dan analisis pendar sinar-x terhadap $z$ warna kuno dan arca Budha.

Hasil pertanggalan radiokarbon telah ditentukan dari berbagai situs. Untuk nenilai kesahihan hasil pertanggalan radiokarbon, telah dilakukan uji banding terhadap cuplikan IAEA. Hasil pengukuran untuk cuplikan kayu Two Creeks (C5) memberikan umur $11360 \pm 83$ tahun, sedangkan hasil pengukuran serupa dibeberapa laboratorium yang dikoordinasikan oleh IAEA (11790 \pm 60 tahun) (Tabel 1). Hasil analisis cuplikan tulang antara lain cuplikan tulang dari situs (Trowulan, Indian USA, dll), cuplikan arang dari situs (Nanga Balang, Indian USA,dll) cuplikan kayu (Pinisi Palembang,dll), cuplikan kerang dari situs (Song Perahu Tuban, Indian USA) serta beberapa cuplikan lainnya yang mengandung karbon(lihat Tabel 2). Untuk cuplikan geologi telah dilakukan studi pendahuluan pada cuplikan organik akibat aktivitas vulkanik atau yang terendapkan bersama sedimen (tanah) pada beberapa lokasi di daerah Watuadeg Kalasan, Sleman Yogyakarta. Daerah ini terletak pada suatu dataran di sebelah utara Zona Pegunungan Selatan yang terisi oleh endapan Kuarter, yang kebanyakan berasal dari G.Merapi (Toha, et.al., 1994). Di lokasi ini tersingkap endapan vulkanik yang beralaskan pasir tufa yang mengandung arang. Endapan alas ini diduga berasal dari endapan awan panas. Endapan pasir berarang ini menumpang di atas paleosoil dari batuan sedimen benumur Tersier 
(Formasi Semilir) yang berupa sedimen laut. Pertanggalan dilakukan pada paleosoil serta pada pasir tufa yang berarang, dengan tujuan untuk mengetahui kapan terbentuknya paleosoil serta kapan endapan awan panas terjadi.

Tabel 1. Analisis antar Laboratorium Radiokarbon Dating untuk Cuplikan IAEA

\begin{tabular}{|c|c|c|c|c|c||}
\hline \multirow{2}{*}{ No. } & Cuplikan & \multicolumn{2}{|c|}{$\mathrm{d}^{13} \mathrm{C}$} & \multicolumn{2}{|c|}{ Umur (BP) } \\
\cline { 3 - 6 } & & PPNY & Lab. lain & PPNY & Lab. lain \\
\hline \hline 1. & $\mathrm{C} 4$ & $-23,5$ & $(-22,0)-(-25,0)$ & $43566 \dot{Y} 2824$ & $44525 \dot{Y} 1385$ \\
\hline 2. & $\mathrm{C} 5$ & $-32,3$ & $(-23,8-(-26,31))$ & $11360 \hat{Y} 83$ & $11790 \hat{Y} 60$ \\
\hline
\end{tabular}

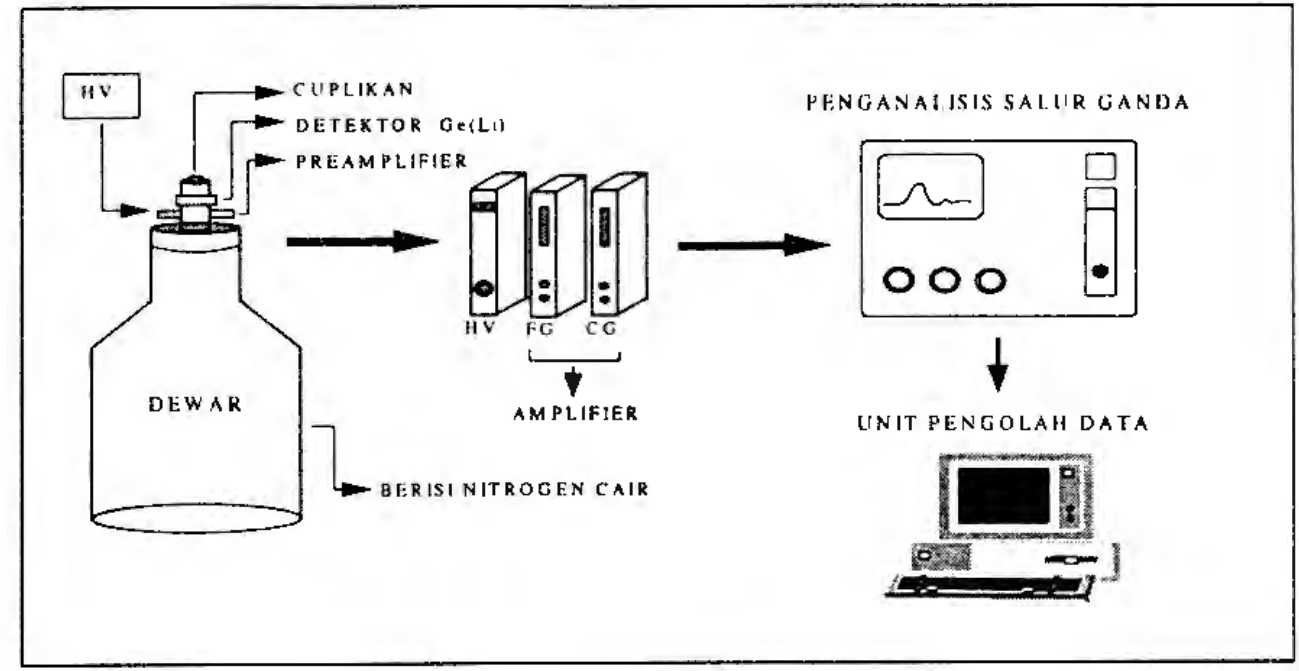

Gambar 1. Alat Spektrometer Gamma

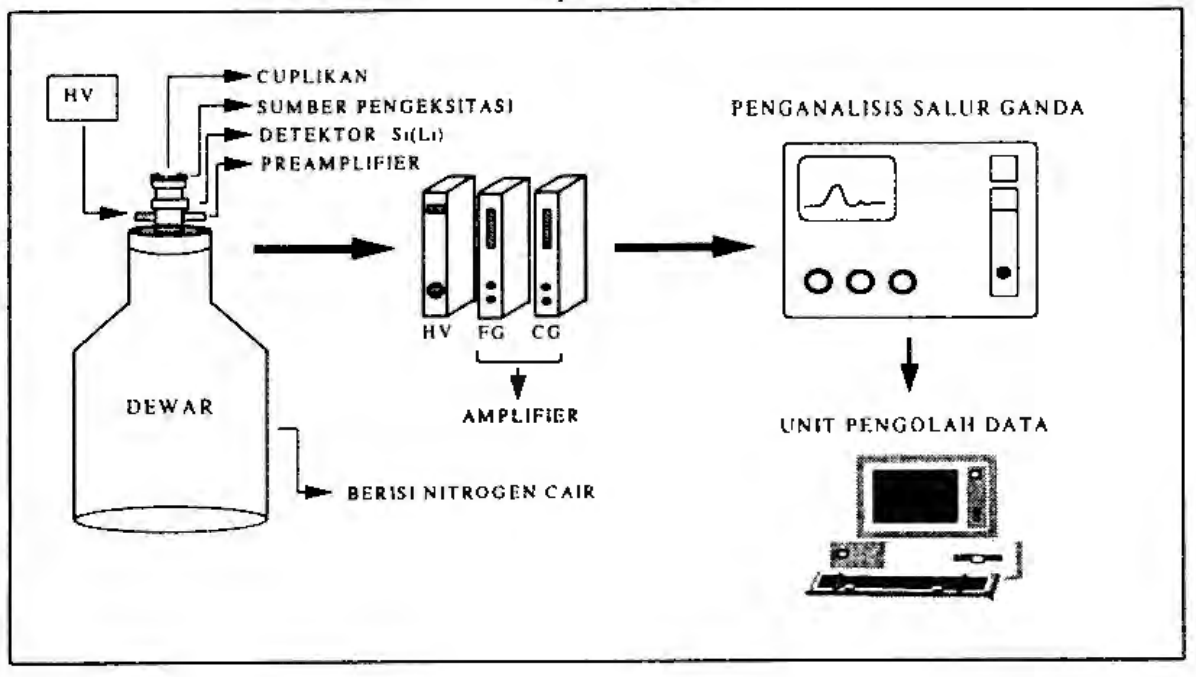

Gambar 2. Alat Pendar Sinar-X. 
Tabel 2. Hasil Pertanggalan Radiokarbon di PPNY-BATAN Yogyakarta

\begin{tabular}{|c|l|c|c|}
\hline No. & \multicolumn{1}{|c|}{ Jenis Cuplikan/Lokasi situs } & $\begin{array}{c}\text { Perkiraan } \\
\text { Pertanggalan (BP) }\end{array}$ & $\begin{array}{c}\text { Hasil Pertanggalan } \\
\text { (BP) }\end{array}$ \\
\hline \hline 1. & Kerang/Indian (USA) & 2000 & $1929,90 \pm 165,54$ \\
2. & Arang/Indian (USA) & 2000 & $1862,54 \pm 158,76$ \\
3. & Tulang/Indian (USA) & 2000 & $1725,95 \pm 155,26$ \\
4. & Kerang/Song Perahu,Tuban,JATIM & $700-10.000$ & $6971,34, \pm 80,48$ \\
5. & Kerang/Song Perahu,Tuban,JATIM & $700-10.000$ & $7041,37 \pm 79,29$ \\
6. & Arang/Nanga Balang & $2450-4000$ & $2871,57 \pm 76,14$ \\
7. & Tulang/Trowulan, JATIM & $472-657$ & $482,20 \pm 61,37$ \\
8. & Kayu/Phinisi, Palembang, SUMSEL & - & $1239,57 \pm 63,22$ \\
9. & Pasir Tuf/Watuadeg, Kalasan & - & $5835,69 \pm 66,91$ \\
10. & Palaesoil /Watuadeg, Kalasan & - & $6127,87 \pm 66,12$ \\
\hline
\end{tabular}

Tabel 3. Hasil Analisis Zat Warna Lukisan Goa dengan Metode Analisis Pengaktifan Neutron

\begin{tabular}{|c|c|c|c|c|c|c|c|c|c|c||}
\hline No. & $\begin{array}{c}\text { Macam } \\
\text { Cuplikan }\end{array}$ & $\begin{array}{c}\text { Kadar } \\
\text { Cr,ug/g }\end{array}$ & $\begin{array}{c}\text { Kadar } \\
\text { Fe,ug/g }\end{array}$ & $\begin{array}{c}\text { Kadar } \\
\text { Co,ug/g }\end{array}$ & $\begin{array}{c}\text { Kadar } \\
\text { Cs,ug/g }\end{array}$ & $\begin{array}{c}\text { Kadar } \\
\text { Mn,ug/g }\end{array}$ & $\begin{array}{c}\text { Kadar } \\
\text { Th,ug/g }\end{array}$ & $\begin{array}{c}\text { Kadar } \\
\text { Se,ug/g }\end{array}$ & $\begin{array}{c}\text { Kadar } \\
\text { fu,ug/g }\end{array}$ & $\begin{array}{c}\text { Kdr } \\
\text { Ce,ug/g }\end{array}$ \\
\hline 1. & Cuplikan 1 & 7,84 & 1,15 & 0,88 & 0,85 & 572,2 & 1,92 & 1,16 & 0,84 & 1,92 \\
\hline 2. & Cuplikan 2 & 7,61 & 0,96 & 0,30 & 0,43 & 429,6 & 1,61 & 0,42 & 0,11 & 7,73 \\
\hline
\end{tabular}

Tabel 4. Hasil Analisis Cuplikan Arca dengan Pendar Sinar-X

\begin{tabular}{|l|l|c|c|c|c||}
\hline No. & \multicolumn{1}{|c|}{ Macam Cuplikan } & $\begin{array}{c}\text { Cacah } \\
\mathrm{Fe}\end{array}$ & $\begin{array}{c}\text { Cacah } \\
\mathrm{Cu}\end{array}$ & $\begin{array}{c}\text { Cacah } \\
\mathrm{As}\end{array}$ & $\begin{array}{c}\text { Cacah } \\
\mathrm{Pb}\end{array}$ \\
\hline \hline 1. & Arca Kuvera & 273,25 & 4814,6 & 29,00 & 276,17 \\
2. & Arca Bodhisatva & 144,80 & 7020,50 & 24,17 & 124,50 \\
3. & $\begin{array}{l}\text { Arca Dhyani Budha } \\
\text { Ratnasamblawa }\end{array}$ & 138,17 & 8799,17 & 125,67 & 206,00 \\
\hline
\end{tabular}

Dari hasil analisis pengaktifan neutron untuk cuplikan lukisan kuno menunjukkan bahwa kandungan beberapa unsur telah dapat diindentifikasi yaitu $\mathrm{Cr}, \mathrm{Fe}, \mathrm{Co}, \mathrm{Cs}, \mathrm{Mn}, \mathrm{Th}, \mathrm{Se}$, Eu dan Ce beserta kandungan masing-masing unsur tersebut (lihat Tabel 3). Sedangkan pada analisis pendar sinar- $\mathrm{x}$ untuk cuplikan arca diperoleh hasil identifikasi beberapa unsur antara lain $\mathrm{Fe}, \mathrm{Cu}, \mathrm{As}$ dan $\mathrm{Pb}$ beserta kandungannya dapat dilihat pada Tabel 4 . 
Dari data tersebut dapat digunakan sebagai perbandingan apabila dikemudian hari ditemukan lukisan atau arca lain yang diragukan keasliannya yaitu dengan membandingkan data unsur antara lukisan asli dengan lukisan palsu maka pemalsuan benda bersejarah tersebut atau benda bersejarah lainnya dapat diketahui. Untuk pengembangan penelitian di masa yang akan datang perlu dilakukan peningkatan kemampuan serta ketrampilan para peneliti aplikasi teknik nuklir yang sudah ada. Perlu dilakukan perencanaan pengadaan alat, memperbaharui (banyak alat yang sudah tua, dan dalam keadaan rusak) serta perawatannya. Mengingat sumber daya manusia yang ada di PPNY BATAN Yogyakarta lebih dititik beratkan pada non paleoantropologi, maka peningkatan sumber daya manusia perlu dilanjutkan.

\section{Pengembangan Teknik Nuklir di Masa Yang Akan Datang}

Dari berbagai pengalaman analisis ditemui berbagai kendala misalnya terbatasnya cuplikan pada analisis penentuan umur (pertanggalan radiokarbon) dan analisis unsur artefak yang sangat bernilai dengan uji tidak merusak. Untuk mengatasi berbagai kendala tersebut telah dilakukan penelitian dan pengembangan antara lain penentuan umur pada cuplikan yang jumlahnya terbatas, dan akan diupayakan pembuatan alat analisis dengan metode thermoluminescence dan sedang dilakukan studi kelayakan awal tentang teknologi yang berbasis akselerator, sehingga kendala-kendala tersebut dapat diatasi, sebagai contoh analisis unsur-unsur dalam artefak (uji tak merusak) dengan metode PIXE, sedangkan pertanggalan radiokarbon, analisisnya menggunakan alat Spektrometer Massa Akselerator (alat ini hanya membutuhkan berat cuplikan dalam orde miligram). Dengan didukung sumber daya manusia dari berbagai disiplin ilmu maka pada waktuwaktu mendatang pemanfaatan teknologi nuklir ini dapat dilakukan dengan lebih komprehensif dan berdaya guna dan berhasil guna.

\section{Kesimpulan}

Dari data hasil analisis di atas menunjukkan bahwa peranan teknik nuklir untuk cuplikan arkeologi sangat bermanfaat dan perlu dikembangkan dan merupakan hal scharusnya dilakukan oleh para ahli umumnya, khususnya bidang arkeologi. Seperti diketahui bahwa analisis dengan metode analisis kimia biasa, mempunyai beberapa kelemahan antara lain belum bisa menganalisis unsur-unsur tertentu, membutuhkan cuplikan yang cukup banyak karena analisisnya untuk satu unsur dibutuhkan satu cuplikan. Sedangkan analisis dengan Pertanggalan relatif yang selama ini dilakukan oleh para ahli arkeologi, akan lebih akurat apabila diikuti dengan pertanggalan absolut. 


\section{KEPUSTAKAAN}

Bertin, E.P., 1978. Introduction to X-Ray Spectrometric Analysis, Plenium Press.

Corliss, W.R. 1964. Neutron Activation Analysis. USAEC N.Y, 27p.

Erdtmann, G and Petri, H., 1986. "Nuclear Activation Analysis, Foundamentals And Techniques". Treatise on Analytical Chemistry. Part 1, Vol. 14.

Faisal, W., Lahagu. F., Dewi. K.,Pujiyono. P., 1991. "Penerapan metode penanggalan radiocarbon dating dengan cara pembakaran kering". Pertemuan dan Presentasi Ilmiah Penelitian Dasar Pengetahuan dan Teknologi Nuklir, PPNY - BATAN, Yogyakarta.

Faisal, W., Pujiyono, P., Prayogo, I., Susetyo, W., Djiyono., Siswanto., 1993. "Pertanggalan Radiokarbon Dari Cuplikan Dalam Jumlah Kecil", Prosiding Pertemuan dan Presentasi Ilmiah Penelitian Dasar Pengetahuan dan Teknologi Nuklir, PPNY-BATAN, Yogyakarta.

Jacob, T., 1971. Kepurbaan Manusia di Asia Tenggara dan Sekitarnya, Berkala IImu Kedokteran Gadjah Mada, Djilid III, No.4, Yogyakarta.

Renfrew, Colin. \& Bahn, Paul. 1991. Archaeology, Theories Methods and Practice. Thames and Hudson, London.

Toha, B., R.D. Purtyasti., Sriyono., Soetoto., W.Rahardjo., P.Subagya.,1994. " Geologi Daerah Pegunungan Selatan : Suatu Kontribusi", Proceedings Geologi dan Geoteknik Pulau Jawa, Sejak akhir Mesozoik hingga Kuarter, ISBN:9768611-004, Yogyakarta. 